\title{
Work Plan for Monitor Well/ GROUND WATER ELEVATION DATA RECORDER INSTALLATION at the Cheney Disposal Site, Grand Junction, Colorado
}

September 1994 
This report has been reproduced from the best available copy. Available in paper copy and microfiche.

Number of pages in this report: 19

DOE and DOE contractors can obtain copies of this report from:

Office of Scientific and Technical Information

P.O. Box 62

Oak Ridge, TN 37831

(615) 576-8401

This report is publicly available from:

National Technical Information Service

Department of Commerce

5285 Port Royal Road

Springfield, VA 22161

(703) $487-4650$ 


\section{DISCLAIMER}

This report was prepared as an account of work sponsored by an agency of the United States Government. Neither the United States Government nor any agency thereof, nor any of their employees, make any warranty, express or implied, or assumes any legal liability or responsibility for the accuracy, completeness, or usefulness of any information, apparatus, product, or process disclosed, or represents that its use would not infringe privately owned rights. Reference herein to any specific commercial product, process, or service by trade name, trademark, manufacturer, or otherwise does not necessarily constitute or imply its endorsement, recommendation, or favoring by the United States Government or any agency thereof. The views and opinions of authors expressed herein do not necessarily state or reflect those of the United States Government or any agency thereof. 


\section{DISCLAIMER}

Portions of this document may be illegible in electronic image products. Images are produced from the best available original document. 
WORK PLAN FOR MONITOR WELL/GROUND WATER ELEVATION DATA RECORDER

INSTALLATION AT THE

CHENEY DISPOSAL SITE, GRAND JUNCTION, COLORADO

September 1994

Prepared for

U.S. Department of Energy

UMTRA Project Office

Albuquerque, New Mexico

Prepared by

Jacobs Engineering Group Inc.

Albuquerque, New Mexico 


\section{TABLE OF CONTENTS}

Section

Page

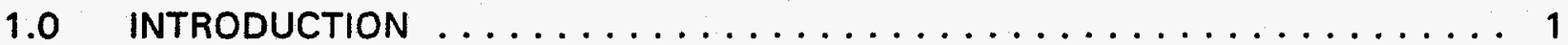

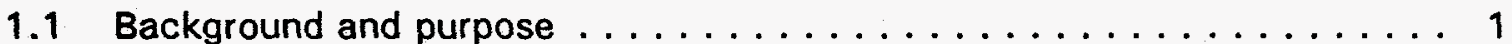

1.2 Data collection objectives $\ldots \ldots \ldots \ldots \ldots \ldots \ldots \ldots \ldots \ldots \ldots$

2.0 MONITOR WELL AND DATA LOGGER INSTALLATION TASKS $\ldots \ldots \ldots$

2.1 Monitor well and data logger locations ............... 3

2.2 Permits, clearances, and access agreements . . . . . . . . . . . 5

2.3 Site conditions ........................ 5

2.4 Well and data logger installation methods $\ldots \ldots \ldots \ldots \ldots \ldots \ldots \ldots$

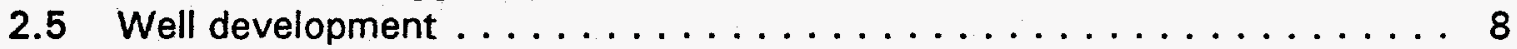

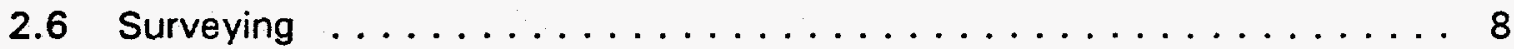

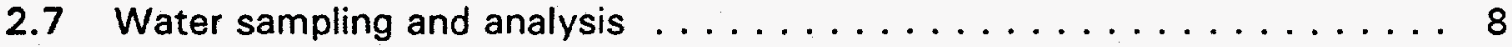

2.8 Site restoration . . . . . . . . . . . . . . . . . . . . 8

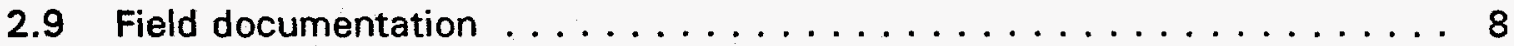

2.10 Anti-contamination measures . . . . . . . . . . . . . . 9

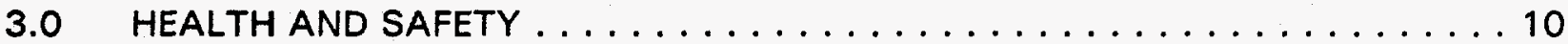

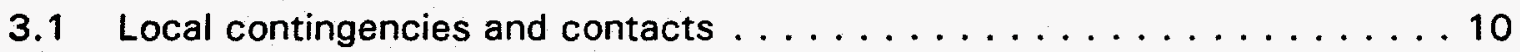

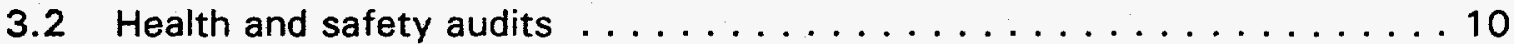

4.0 MONITOR WELL INSTALLATION TASK SCHEDULE $\ldots \ldots \ldots \ldots \ldots \ldots$

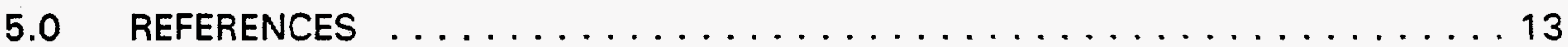




\section{LIST OF FIGURES}

\section{Figure}

2.1 Proposed paleochannel monitor well/data logger locations, Cheney disposal

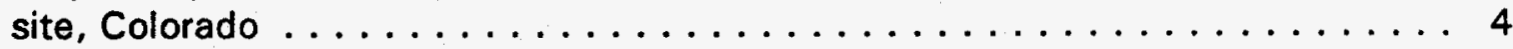

2.2 Typical monitor well/data logger installation $\ldots \ldots \ldots \ldots \ldots \ldots$

3.1 Route to hospital from Cheney disposal site, Colorado . . . . . . . . . . 11 


\section{LIST OF ACRONYMS AND ABBREVIATIONS}

\section{Acronym Definition}

DCO Data collection objectives

DOE

$\mathrm{ft}$

U.S. Department of Energy

feet

FTR

field technical representative

MKES

Morrison Knudson Environmental Services

PRS

Project Regulatory Specialist

PVC

polyvinyl chloride

RAC

Remedial Action Contractor

SOP

Standard Operating Procedure

TAC

Technical Assistance Contractor

UMTRA

Uranium Mill Tailings Remedial Action 


\subsection{INTRODUCTION}

\subsection{BACKGROUND AND PURPOSE}

In May 1990, during the excavation for the Grand Junction, Colorado, Cheney Reservoir disposal cell (Cheney), a water bearing paleochannel was encountered along the northern boundary of the excavation. The paleochannel was designated as the Northwest Paleochannel. This paleochannel had not been identified during previous site investigations. To ensure the long-term integrity of the disposal embankment, remedial actions were taken. Remedial actions included the excavation of the paleochannel and underlying material to bedrock (Mancos Shale), backfilling of the trapezoidal trench with granular material, and placement of a geotextile liner above the granular material. Compacted clay backfill was then placed above the reconstructed paleochannel trench, and the northwest corner of the site was restored to the designated grade. According to Morrison Knudson Environmental Services (MKES) (1992), the reconstructed Northwest Paleochannel was completed as designed.

During field activities in 1989 and 1990, a number of other paleochannels were previously found to exist east of the disposal cell. Investigation of these paleochannels determined that ground water flow terminated before it migrated as far west as the disposal cell. Therefore, flow in these paleochannels would have no impact on the disposal cell. Although characterization efforts did not indicate the presence of a ground water-bearing paleochannel south of the disposal cell, the potential could not be ruled out.

As a best management practice for long-term monitoring at Cheney, two monitor wells will be installed within the paleochannels, one near the northwestern corner and one near the southwestern corner of the disposal cell. The northwestern well will be installed within 50 feet $(\mathrm{ft})$ west of the reconstructed Northwest Paleochannel. The second well will be installed near the southwestern (downgradient) corner of the disposal cell. The purposes of these wells are to characterize ground water flow (if any) within the paleochannels and to monitor the potential for water movement (seepage) into or out of the disposal cell. Initial monitoring of the paleochannels will consist of water level elevation measurement collection and trend analysis to evaluate fluctuations in storage.

The purpose of this document is to describe the work that will be performed and the procedures that will be followed during installation of two ground water monitor wells and two ground water elevation data recorders (data loggers) at Cheney. 


\subsection{DATA COLLECTION OBJECTIVES}

Data collection objectives (DCO) identify reasons for collecting data. The following are DCOs for the Cheney monitor well/ground water elevation data recorder installation project:

- Detect ground water occurrences (if any) within the subject paleochannels.

- Evaluate ground water occurrences by measuring static ground water levels; and, upon detection, assess any fluctuations in ground water levels.

- Depending on evaluation of static ground water level data, sample detected paleochannel waters to determine changes in chemistry and possible cell impacts. 


\subsection{MONITOR WELL AND DATA LOGGER INSTALLATION TASKS}

\section{1}

\section{MONITOR WELL AND DATA LOGGER LOCATIONS}

Two ground water monitor wells will be installed, one near the northwest corner and one near the southwestern corner of Cheney. Data loggers will then be installed in the wells to monitor ground water levels in the basal portion of the paleochannels. The approximate monitor well/data logger locations and the general location of the Northwest Paleochannel are shown in Figure 2.1.

The northwest well will be placed slightly west of the reconstructed portion of the Northwest Paleochannel. This will place the well west of the backfill material and west of the geotextile liner that was placed over the gravel to protect the gravel from the migration of fines.

It is anticipated that the southwestern well will be placed slightly east of Test Pit No. 106 (Figure 2.1). Test Pit No. 106 was excavated in 1989 and was the westernmost test pit at the Cheney site. This test pit area is located hydraulically downgradient when considering regional ground water flow. During the original investigation of the Cheney site, significant evidence of a water-bearing paleochannel was not obtained southwest of the cell. However, due to suspected seasonal or cyclic flow within paleochannels, the potential occurrence of ground water could not be ruled out. The final location of the southwestern well will be based on analysis of available test pit information and information supplied by MKES and Jacobs Engineering Group Inc., Technical Assistance Contractor (TAC), employees who were present at the time of investigation.

Although the approximate locations of the paleochannel wells have been selected, the actual monitor well locations will be chosen in the field with the aid of an MKES representative who was involved with the northwest paleochannel restoration and overall Cheney site characterization. If drill cuttings do not indicate the presence of a paleochannel within the wellbore, the wellbore will be plugged. The drill rig will then be moved to an alternate nearby location where the wellbore will be drilled into the paleochannel.

Once installed, the monitor wells will be situated so that the screened intervals straddle the paleochannels; the data loggers will be set at the very bottom of the screened intervals to record a minimum of six water level measurements per day for a minimum of 1 year. Field technicians will download the recorded data to a personal computer and check the data logger for proper operation at approximately 3-month intervals. 


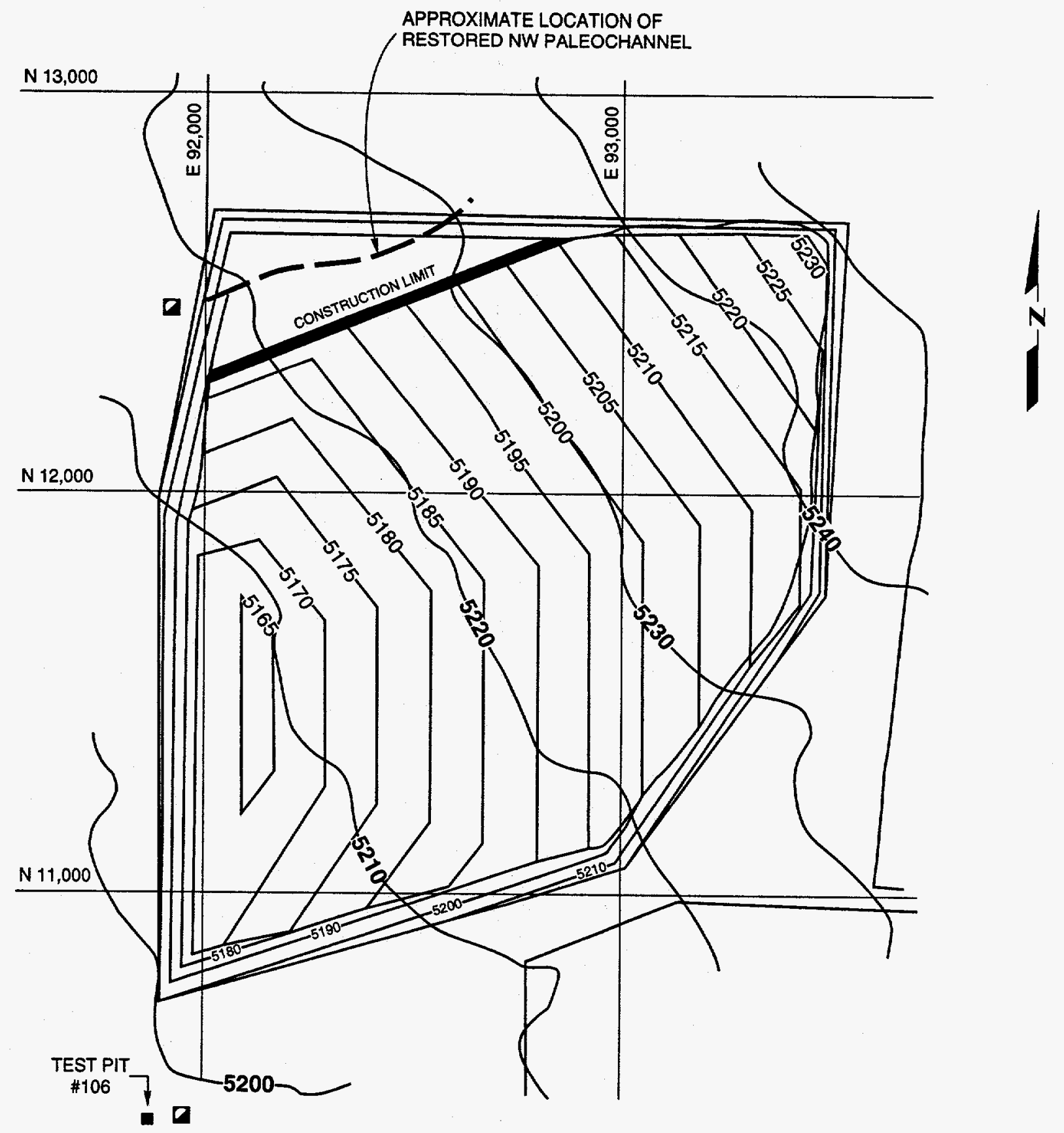

LEGEND

PROPOSED PALEOCHANNEL MONITOR WELL/DATA LOGGER LOCATION

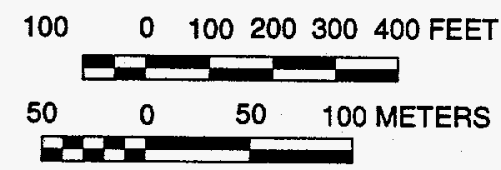

-5230- EXISTING GROUND CONTOUR

- 5180 - EXCAVATION CONTOUR

REVISED FROM: MKES (1992)

FIGURE 2.1

PROPOSED PALEOCHANNEL MONITOR WELLIDATA LOGGER LOCATIONS CHENEY DISPOSAL SITE, COLORADO 
The proposed monitor wells (Figure 2.1) have current access agreements in place. These new monitor wells will, however, also require monitor well permits from the state of Colorado.

The Colorado Division of Water Resources has been contacted by the Project Regulatory Specialist (PRS) for permitting information and a notification of intent to install monitor wells has been submitted. The state of Colorado doesn't require that long-term well permits be in place prior to drilling. The PRS will apply for and obtain the actual well permits later this year. Property Management will obtain any needed access agreements before any field work is initiated.

\section{SITE CONDITIONS}

In the vicinity of Cheney, the geology consists of 25 to $40 \mathrm{ft}$ of colluvium and alluvium that consists of clays, silts, sands, gravels, and cobbles. This surficial material overlies approximately 600 to $700 \mathrm{ft}$ of weathered and unweathered Mancos Shale.

Based on field observations during the Northwest Paleochannel reconstruction effort, the paleochannel is located at an approximate depth of $20 \mathrm{ft}$ below original ground surface. The width of the paleochannel ranges between 5 and $20 \mathrm{ft}$ and the thickness ranges between $3 \mathrm{ft}$ and $5 \mathrm{ft}$. The paleochannel is trending in a general easterly-northeasterly direction from the proposed well location.

Although the colluvial and alluvial materials that will be encountered at the southwest location should be similar to those encountered at the northwest well location, less specific data regarding subsurface conditions are available. As previously mentioned, there were a number of test pits logged in the area. Information from these test pit logs, in conjunction with information supplied by MKES and Jacobs Engineering personnel who were present during the time of the investigation, will be used to place the southwest well.

\section{WELL AND DATA LOGGER INSTALLATION METHODS}

Because of the heterogeneous nature of the alluvial materials and the presence of cobbles, the air rotary casing advance drilling method will be used to install the monitor wells. Monitor wells will be installed according to Uranium Mill Tailings Remedial Action (UMTRA) Project Standard Operating Procedure (SOP) 14.3.1, Drilling Procedures (JEG, n.d.). The wells will be approximately 20 to $30 \mathrm{ft}$ deep and consist of approximately $5 \mathrm{ft}$ of 4 -inch diameter polyvinyl chloride (PVC) well screen (placed slightly below the bottom of the paleochannel and up $5 \mathrm{ft}$ ) and approximately 10 to $20 \mathrm{ft}$ of 4-inch diameter PVC casing (Figure 2.2). Well construction materials and hand tools will be supplied by a licensed well driller contracted through the TAC. 


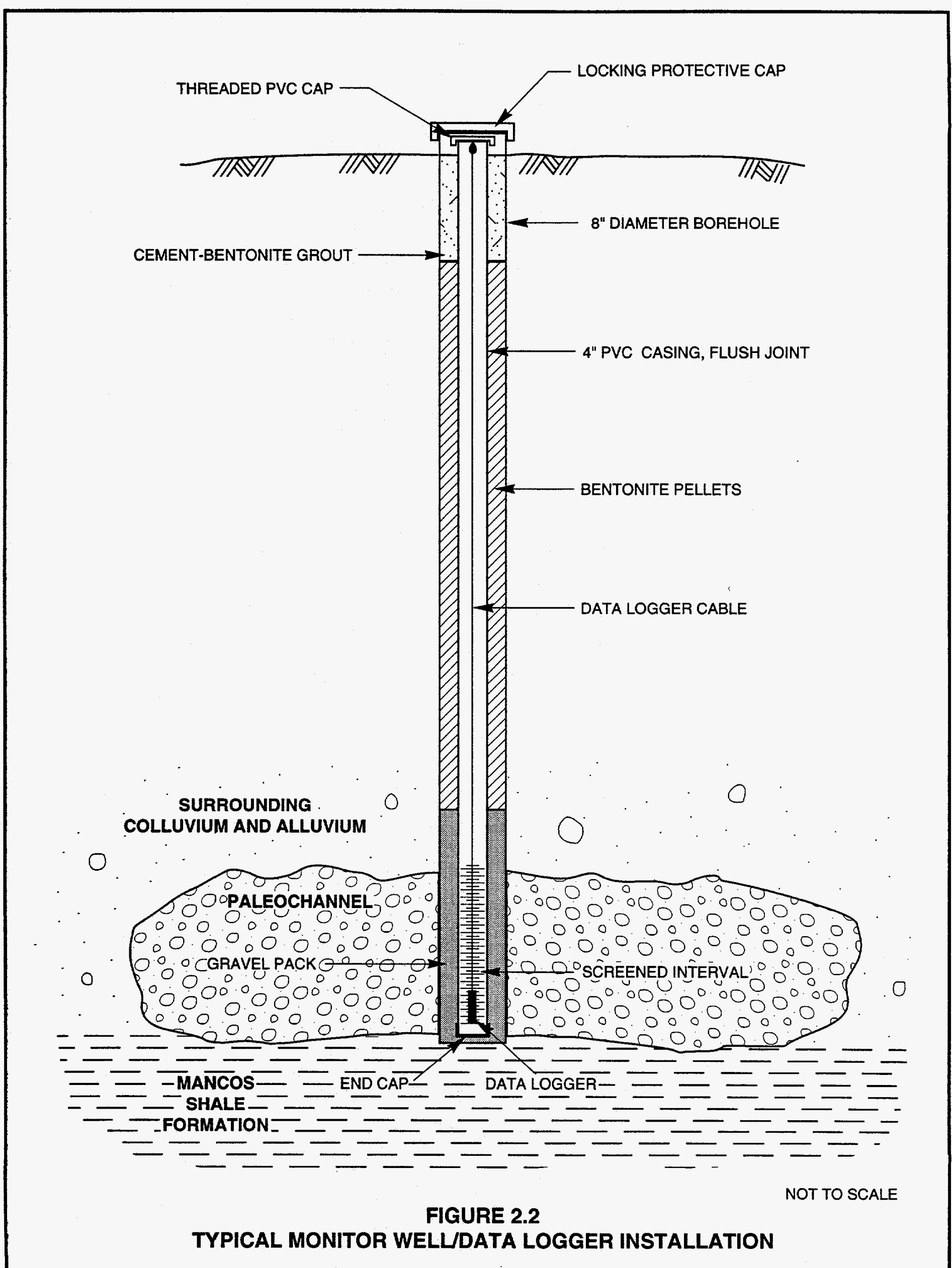


Data loggers and pressure transducers will be installed and calibrated in each monitor well following the manufacturer's instructions. Data loggers will be suspended in the monitor well for approximately 30 minutes to allow for cable stretch, water level equalization, and proper temperature equilibration between the ground water and data logger. Proper data logger operation will be verified by comparing the water level reading given by the data logger to the actual water level reading determined with a water level probe. Length of transducer cable will vary depending on depth to water and anticipated water level fluctuations in the monitor well. Existing ground water data, such as depth to water and historical water level fluctuations, will be reviewed to ensure data loggers and pressure transducers are installed so that the instruments operate properly throughout the year.

To verify proper data logger operation, data loggers will be checked immediately after installation by field personnel. Approximately 2 weeks after installation, the data logger operation will again be verified by field personnel. Once proper data logger operation is ensured, data will be downloaded at approximately 3-month intervals.

In addition to the SOP mentioned above, the following applicable SOPS will be followed during monitoring well installation (JEG, n.d.):

14.1.2 Instructions for Field Technical Representative

14.1.3 Drilling and Test Pit Technical Representative

14.1.4 Verification of Grout Mix for Monitor Wells

14.1.5 [Field Technical Representative] FTR Daily Diary

14.1.6 Procedures for Completing the Daily Field Activity Report

14.1.7 Field/Off-Site Procurement of Supplies \& Services

14.3.1 Drilling Procedures

14.4.1 Soil and Rock Core Borehole and Test Pit Logging

14.4.2 Preparation of Logs for [UMTRA Project] UMTRAP Documents

16.1.1 Monitor Well Installation

16.1.2 Well Development

16.1.19 Permitting Procedures for Installation or Decommissioning of Monitor Wells

16.1.22 Controlled Disposal of Potentially Contaminated Materials 


\subsubsection{Location [Identification] ID for Test Borings, Test Pits, and Monitoring Locations}

Internal communications will be maintained among the field representatives, site hydrogeologists, the TAC Contracts Department and Property Management, the site manager, and the U.S. Department of Energy (DOE). Before any installation of wells or loggers occurs, the Remedial Action Contractor (RAC) site manager will be notified of the upcoming activities, and the work party will check in with the RAC. Any problems or complications encountered during field work will be reported to the TAC site manager, who will forward the information to the DOE.

\subsection{WELL DEVELOPMENT}

No sooner than 48 hours after completion of the wells, the wells will be developed according to SOP 16.1.2 until the discharge is clear. The amount of water removed and approximate well yields will be recorded. The appropriate procedures will be followed to ensure development water is properly disposed. If there is insufficient water to allow for development of the wells, development will not be conducted. In this case, use of the air rotary casing advance drilling method should still allow for adequate hydraulic connection between the well screen and formation.

\subsection{SURVEYING}

Once the monitor wells have been installed, they will be surveyed by a local surveying contractor to establish top of casing elevation and Colorado State Plane Coordinates. Monitor well top-of-casing elevations will be surveyed to the nearest $0.01 \mathrm{ft}$.

\subsection{WATER SAMPLING AND ANALYSIS}

No water quality samples will be taken at this time, although the wells may be sampled in the future.

\section{SITE RESTORATION}

Moderate site disturbance is anticipated. However, areas of disturbed soil will be raked smooth by hand; all trash will be collected immediately; and established roadways and paths will be used whenever possible.

\subsection{FIELD DOCUMENTATION}

In addition to the daily diary kept by the field technical representative (FTR) the following documentation will be compiled and data collected:

- The monitor well locations will be photographed before and after installation of the well and located on a map. The top-of-casing elevations and the 
state plane coordinates for the wells will be surveyed by the surveying subcontractor.

- Total depth of well, depth to water, and total length of the water column in the well will be recorded prior to and following development.

- Specific conductance, $\mathrm{pH}$, and temperature will be recorded during development. A final set of measurements will be taken after development is complete.

- The water level elevations at the new well locations will be recorded at least once just before the data loggers are installed in the wells.

- Proper functioning of the data loggers will be verified by recording the depth to water as reported by the data logger and a water level probe.

Copies of all pertinent field documentation will be maintained in the UMTRA Project Document Control Center.

\subsection{ANTI-CONTAMINATION MEASURES}

Before being taken onto the site, all well installation materials, including the drill rig, will be cleaned to the FTR's satisfaction. The TAC FTR will inspect equipment for the presence of hydraulic oil or grease and, if necessary, the equipment will be steam cleaned to remove such material. 


\subsection{HEALTH AND SAFETY}

\subsection{LOCAL CONTINGENCIES AND CONTACTS}

All personnel involved with monitor well and data logger installation will have the following equipment:
- Hard hat
- Steel-toed boots
- Work gloves
- Sunblock lotion
- Fresh drinking water

The following items will be on-site:
- First-Aid kit
- Fire extinguisher
- Cellular telephone

The nearest hospital, in case of emergency, is St. Mary's Medical Center (303-244-2551) in Grand Junction, Colorado. The phone number for all emergencies is 911. A map showing the route to St. Mary's Medical Center is included in this work plan (Figure 3.1).

\subsection{HEALTH AND SAFETY AUDITS}

The FTR will be responsible for observing that subcontractor personnel work activities are in compliance with UMTRA Project health and safety requirements and that Occupational Safety and Health Administration codes 29 CFR Parts 1910 and 1926 (1994) are followed during all phases of well installation. The applicable SOPs (JEG, n.d.) are as follows:

7.3.1 Occupational Safety and Health Complaints

7.3.2 Occupational Safety and Health Complaints for TAC Subcontractors

14.1.2 Instructions for Field Technical Representative 


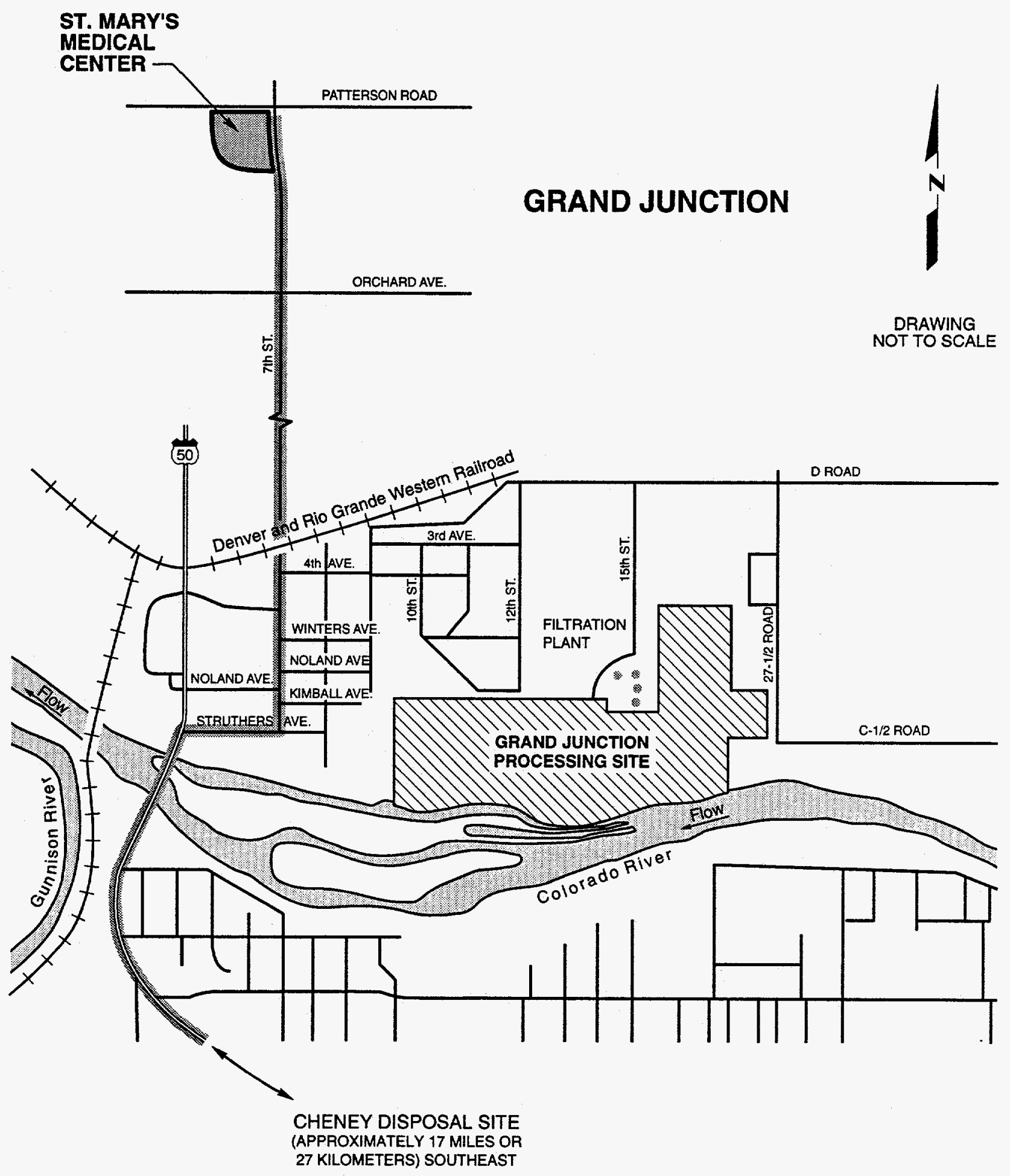

FIGURE 3.1

ROUTE TO HOSPITAL FROM

CHENEY DISPOSAL SITE, COLORADO 


\subsection{MONITOR WELL INSTALLATION TASK SCHEDULE}

The tasks and accompanying tentative completion dates for this work plan are as follows:

\begin{tabular}{|c|c|}
\hline Task & Completion \\
\hline Site visit & July 8,1994 \\
\hline Well permits" & August 15, 1994 \\
\hline Access agreements & August 15, 1994 \\
\hline Drilling subcontract award & September 8, 1994 \\
\hline Field operation readiness evaluation & August 31,1994 \\
\hline Equipment procurement & September 16, 1994 \\
\hline Mobilization/wells installation & November 1, 1994 \\
\hline Wells survey & November 4, 1994 \\
\hline Data logger installation & November 4, 1994 \\
\hline Data logger operation check & December 6, 1994 \\
\hline
\end{tabular}




\subsection{REFERENCES}

JEG (Jacobs Engineering Group Inc.), n.d. Albuquerque Operations Manual, Standard Operating Procedures, prepared by Jacobs Engineering Group Inc., Albuquerque, New Mexico, for the U.S. Department of Energy, UMTRA Project Office, Albuquerque Operations Office, Albuquerque, New Mexico.

MKES (Morrison Knudson Corporation Environmental Services Group), 1992. "Northwest Paleochannel Restoration at Cheney Disposal Embankment Site," prepared by Morrison Knudson Corporation Environmental Services Group, San Francisco, California, for the U.S. Department of Energy, UMTRA Project Office, Albuquerque Operations Office, Albuquerque, New Mexico.

\section{CODE OF FEDERAL REGULATIONS}

29 CFR Part 1910, Occupational Safety and Health Standards, Occupational Safety and Health Administration, Department of Labor (1994)

29 CFR Part 1926, Safety and Health Regulations for Construction, Occupational Safety and Health Administration, Department of Labor (1994). 